\title{
PHRASEOLOGICAL UNITS WITH "COSMONYM" COMPONENT IN ENGLISH
}

\author{
Tatyana Kolesova ${ }^{1 \star}$, Ksenia Vavilova ${ }^{2}$, Galina Kazyro ${ }^{3}$, Galina Trapeznikova ${ }^{4}$, Andrey \\ Rychkov $^{5}$ \\ ${ }^{1}$ Assoc.Prof, FSBEI HE "Mari State University", Russia, tatcos@yandex.ru, \\ ${ }^{2}$ Assoc.Prof, FSBEI HE "Mari State University", Russia, vuk_2004@mail.ru, \\ ${ }^{3}$ Assoc.Prof, FSBEI HE "Mari State University", Russia, galinarfa@yahoo.com, \\ ${ }^{4}$ Assoc.Prof, FSBEI HE "Mari State University", Russia, galinatra@gmail.com, \\ ${ }^{5}$ Assoc.Prof, FSBEI HE "Mari State University", Russia, rychkovandre@yandex.ru \\ ${ }^{*}$ Corresponding Author
}

\begin{abstract}
The article focuses on phraseological units containing components "cosmonyms" with anthropocentric characteristic in English. Within the study 49 phraseological units with elements - cosmonyms were selected which were decomposed into semantic components. The object of the research was phraseological units of English and French with cosmonym components having anthropocentric characteristics. The subject of research is semantic features of these phraseological units. Selected phraseological units carry characteristics of a person and his activities. The purpose of this study is to analyze English and French phraseological units with cosmonym components. To carry out the research the authors used general scientific and linguistic methods and techniques. In this work, it is necessary to highlight the use of a cognitive approach characterizing the orientation of the language to the description of a person and his activities. When considering the semantic features phraseological units with components - cosmonyms in this work were the following research methods were used: the method of continuous sampling of material from phraseological dictionaries; method of synthesis and analysis used in identifying the semantic features of phraseological units; method of classification, with the help of which it was possible to arrange the analyzed idioms in the desired sequence; quantitative method that allowed to compare quantitative data and process the results of a selection from English dictionaries; methods of observation and generalization. The author of the article offers an ideographic classification of selected phraseological units. As part of the study the semantics of phraseological units of the English language with components of cosmonyms is analyzed. The practical significance lies in the fact that the results research will help to systematically present the use of phraseological units with components - cosmonyms for describing a person's character in English.
\end{abstract}

Keywords: Phraseological units, ideographic classification, cosmonyms, anthropocentric characteristics, English phraseology, semantic field, semantics, meaning, human characteristics, solid method, sampling.

\section{INTRODUCTION}

The development and study of phraseology as a science has been going on for a long time. When studying the language, it is important to know its grammatical and lexical composition, but in order to deeply understand the language, it is important to refer to its phraseological composition. Studying of phraseology of the language is extremely important, since the phraseological units convey the experience accumulated by the people, and they are a kind of reflection of the linguistic picture of the world. 
Phraseology is often called the treasury of the language, which accumulates both old and new phraseological units. Phraseological units are used in everyday communication and in literature.

\section{LITERATURE REVIEW}

Both Russian and foreign researchers were engaged in the study of phraseology. Thus, the methodological basis of this study was the works of Russian and foreign researchers: A. V. Arnold (Arnold, 1973), Sh. Bally (Sh. Bally, 2001), V. V. Vinogradov (Vinogradov, 1977), A. V. Kunin (Kunin, 1996), B. A. Larin (Larin, 1977), A.I. Smirnitsky (Smirnitsky, 1956), Ch. Hockett (Hockett, 1958), S. Gramley (Gramley, 1992).

The material of the research was the phraseological units of the English language, selected by the method of continuous sampling from the dictionaries "English-Russian Phraseological Dictionary" by A.V. Kunin (Kunin, 1972), "Oxford Dictionary of Idioms" (Siefring, 2004), "Oxford Dictionary of Proverbs" (Speake, 2008), "Cambridge International Dictionary of Idioms" (2002).

The selected dictionaries as lexicographic sources are relevant for the practical study of the phraseology of the English language.

\section{METHODOLOGY}

In this work, phraseological units with components - cosmonyms with anthropocentric characteristics in the English language were analyzed. In the course of the work, 49 phraseological units with elements cosmonyms were selected from the above lexicographic sources, which were decomposed into semantic components.

During the research, various methods and techniques were used, both general scientific and linguistic. With their help, it was possible to describe in detail the material being analyzed. In this work, it is necessary to highlight the use of a cognitive approach that characterizes the orientation of the language to describe a person and his activities.

When considering the semantic features of phraseological units with components - cosmonyms, the following methods were used in this research: method of continuous sampling of material from phraseological dictionaries; method of synthesis and analysis used to identify semantic features of phraseological units; the method of classification, with the help of which it was possible to arrange the analyzed idioms in the required sequence, i.e. into separate semantic groups, reflecting the meaning of phraseological units and highlighting some sign; the quantitative method, which made it possible to compare quantitative data and process the results of a sample from English dictionaries; methods of observation and generalization, with the help of which the results were obtained and conclusions were drawn.

\section{FINIDINGS}

To identify the anthropocentric characteristics of linguistic units, namely phraseological units, it is necessary to understand their semantic features.

49 phraseological units of the English language were selected with components - cosmonyms that characterize a person. The group of English phraseological units includes lexemes containing the following components: sun, star, sky, moon, orbit, rocket, atmosphere, space, planet, Mars, Earth. Selected phraseological units with these components characterize a person from different sides such as character traits, emotions, activities, etc.

Based on the analysis of the values of the units under study, the following ideographic classification of phraseological units of the English language was created. Phraseological units with cosmonym components with anthropocentric characteristics are concentrated in the conceptual field - "Human". This conceptual field was divided into several semantic groups: "Man as a living and intelligent being", "Human activity" and "Independent from the person himself". The quantitative distribution of semantic fields differs markedly.

The division of phraseological units by semantic fields is proportional. A smaller part of phraseological units is distributed in the conceptual field "Independent of the Person Himself" and is only $18 \%$ of the total number of idioms (10 phraseological units of the English language). $27 \%$ of phraseological units are in the conceptual field "Man as a living and intelligent being" (17 English phraseological units).

The conceptual field "Human Activity" is the most extensive and includes $55 \%$ of phraseological units (22 phraseological units of the English language). Hence, we can conclude that the description of human activity occupies an important place in this ideographic classification, i.e. components - cosmonyms are more often used to characterize a person's activity, and not to describe his appearance, character traits, etc. 
It is worth noting that each concept field has several sections. The characteristic of a person as a living and intelligent being has 17 phraseological units that characterize the appearance, social status, character traits, emotional state and emotions, as well as physical condition.

A large number of English phraseological units describe the emotional state of a person in different ways. The range of emotions in the English language is presented extensively. With the help of phraseological units with components - cosmonyms, an English-speaking person expresses joy, calmness, grief and anger. For description of joy, the English use the following phraseological units: be / jump over the moon (literally to be / jump above the moon) - to jump for joy, to be in seventh heaven (from happiness); over the moon (lit. above the moon) - very joyful, happy.

A positive assessment of the emotional state, namely calmness, is represented by the phraseological unit as calm as a toad in the sun (lit. calm like a toad in the sun) - very calm and contented. Phraseological units go into the orbit (literally go beyond the orbit) - to get angry, angry, burst with anger, climb the wall with anger; go off like a rocket (lit. to fly out as rocket) - flare up, explode have a negative assessment and express anger.

Phraseologism moon something away - cry for a long time, grieve is used to describe sadness and grief. It follows from this that in the English-speaking world the studied components are widely used in the description and definition of the emotional background of a person.

In the course of studying the phraseological fund, only 1 phraseological unit was identified with a component - A cosmonym, which describes a person's appearance. PU like a full moon (lit. like a full moon) - round like the moon describes a certain feature of the face of a man or woman, namely its shape.

A person's social status can be defined as both low and high. Examples of phraseological units that characterize a person's low social status: a spent rocket (lit. sent rocket) - "extinct sun", i.e. a person who is no longer in demand in his field of activity [Kunin, 1984, p. 639]; cover with the moon (lit. covered by the moon) - to sleep in the open air (about the unemployed and not having a shelter), i.e. do not have a roof over their heads. This phraseological unit is used for characteristics of the unemployed and homeless people. PU rising star - a rising star can be regarded as a characteristic of a successful person, his high social status. From this we can conclude that cosmonyms often serve as a symbol of a certain well-being of people.

While working with dictionaries, several phraseological units were identified with components - cosmonyms that characterize the traits of a person's character. English phraseological units give a negative assessment of a person's character, describing him as vain or crazy. So, PU aim / level at the moon (literally aim / align at the moon) is used in the meaning of "to be vain, ambitious, to aim high" and PU a space cadet (lit. space cadet) - crazy.

In the conceptual subgroup "Physical State", only one phraseological unit to be in the sun / sunshine (lit. being in the sun / sunlight) was identified - to be drunk.

In the semantic group "Human Activity" during the analysis, the following subgroups were identified: "Activity without naming the action itself", which includes 5 phraseological units, and "Activity in a team", which includes 13 phraseological units with components - cosmonyms.

When characterizing human actions, it is noted the complexity of the action itself (ask / cry / wish for the moon (literally ask / pray / wish for the moon) - ask for the moon from heaven, wish, demand the impossible; reach for the stars (lit. to reach the stars) - to have high, hard-to-reach goals) and ways of performing an action (bless / thank one's stars (lit. bless / thank the stars) - bless, thank your destiny [Kunin, 1984, p. 714]; follow one's star (lit. follow the star) - follow your destiny, to execute predetermined by fate). The image of a star is associated in English phraseology with fate, with a chance, i.e. the British believe in the predetermination of the future.

A person is a social being who is in constant communication with other people, therefore it is impossible not to single out the conceptual field "Teamwork". The largest number of phraseological units characterizes actions in relation to another person (adore the rising sun (lit. to adore the rising sun) - curry favor with the new government, seek mercy from a person gaining power; extol / laud / praise smb. to the skies (lit. to praise / praise someone before heaven) - praise, extol someone to heaven; persuade smb. that the moon is made of green cheese (lit. to convince someone that the moon is made of young cheese) - to prove to someone the obvious absurdity, to deceive and think the sun shines out / of sb 'sarse / backside (lit. to think that the sun shines from both front and back) - to love someone so much that you don't notice his mistakes and shortcomings. Also, a person can exist as an independent unit, outside of society, therefore, we can 
highlight the section "Action performed independently". This section is not presented so extensively, but it should be noted such phraseological units as boast above the moon (lit. to brag above the moon) - to brag, not know the measure in boasting.

Things can happen in a person's life, events that do not depend on the individual, so the English-speaking world is rich in such phraseological units: be born under a lucky star - born under a lucky star, be born under an unlucky star - to be born under an unlucky star, be through with one's star (lit. to break with someone's star) - fail, lose popularity, have one's star in the ascendant (literally, to have a star in power) - to be lucky, to succeed, to go uphill.

\section{CONCLUSION}

From the analysis of phraseological units with components - cosmonyms with anthropocentric characteristics, it follows that the phraseological series characterizing human activity is much more extensive. This conclusion can be explained by emotional restraint and strict education of representatives of the English-speaking world.

\section{REFERENCE LIST}

Arnold, I.V. (1973). Lexicology of Modern English

Bally, Sh. (2001). French Stylistics

Cambridge International Dictionary of Idioms (2002)

Kunin, A.V., Litvinov, M. D. (1984). English-Russian Phraseological Dictionary

Kunin, A. V. (1972). Phraseology of Modern English

Kunin, A. V. (1996). The Course of Phraseology of Modern English

Larin, B. A. (1977). History of the Russian Language and General Linguistics

Smirnitskiy, A. I. (1956). Lexicology of the English Language

Hockett, Ch. (1958). A Course in Modern Linguistics

Gramley, S. (1992). A survey in Modern English

Siefring, J. (2004). Oxford Dictionary of Idioms. Oxford

Speake, J. (2008). The Oxford Dictionary of Proverbs. Oxford: Oxford University Press

Vinogradov, V. V. (1977). Selected Works. Lexicology and Lexicography 